\title{
SIMULTANEOUS DETERMINATION OF STEVIOL GLYCOSIDES IN FOOD FROM STEVIA BY LIQUID CHROMATOGRAPHY TANDEM MASS SPECTROMETRY (LC-MS/MS)
}

\author{
Luu Thi Huyen Trang ${ }^{1}$, Vu Thi Kim Oanh, Vu Thi Trang, Nguyen Thi Bien \\ National Institute for Food Control
}

(Received on: 27/3/2019; Revised on: 23/5/2019; Accepted on: 31/5/2019)

\section{Abstract}

The objective of this study is to develop a method for determination of steviol glycosides in food using liquid chromatography mass tandem spectrometry. The compounds were extracted from the matrices with methanol at $40^{\circ} \mathrm{C}$ within 60 minutes, and then determined by LC-MS/MS using C18 column $(100 \mathrm{~mm} \times 2.1 \mathrm{~mm} \times 3.5 \mu \mathrm{m})$, the MS/MS detector with negative ESI mode. The calibration curves were linear in the range of 0.1 to $20 \mu \mathrm{g} / \mathrm{mL}$; the RSD was of $1.74-5.01 \%$; and the recovery was in range of $90-105 \%$. The method was applied to analyze 20 food samples collected from markets in Hanoi (including dry stevia rebaudiana, stevia powder, stevia tea and soft drinks). The results showed that the composition of steviol glycosides was different from sample to sample. The most abundant steviol glycosides were stevioside and rebaudioside A.

Keywords: LC-MS, steviol glycosides, stevia.

\section{INTRODUCTION}

In recent years, the consumption of a large amount of sugar has caused negative effects on consumers' health, including obesity and diabetes. Diabetes is a dangerous and global disease; it brings harmful effects and great consequences to society. Therefore, manufacturers have used low-calorie sweeteners to replace sugars, such as saccharin, cyclamate, sucralose, acesulfame K and aspartame [7]. These synthetic sweeteners have high sweetness and low cost; however, there have been reports on their toxicity and side effects to human health. To solve this problem, natural sweeteners are studied to replace them.

Steviol glycosides are a group of naturally sweet compounds derived from Stevia rebaudiana leaves, which are 75 to 300 times sweeter than cane sugar. They are used for the treatment of diabetes, hypoglycemia, obesity, tooth decay, hypertension, antimicrobial, antifungal, antiviral, and antiinflammatory products. As a result, these natural sweeteners are required for production and consumption. Steviol glycosides are added to the products which are used for people who need to take a limited amount of sugar, such as bakery products, candies, soft drinks and diet products. The joint FAO/WHO Committee for Food Addtives (JECFA) offers an acceptable daily intake (ADI) of these compounds of $4 \mathrm{mg} / \mathrm{kg}$ body weight/day.

In order to control steviol glycoside content in materials and products, it is necessary to develop analytical methods. Some international studies were published for determination of steviol glycoside including: high performance liquid chromatography with UV-Vis detector [2, 3]; liquid chromatography mass spectrometry [4, 5, 6, 7]. The LC-MS/MS method exhibits a number of advantages such as fast analysis, short time, high sensitivity and simultaneous identification of compounds with similar properties and structures.

\section{${ }^{1}$ Tel:0963385124 Email: luutrang1710@gmail.com}




\section{MATERIALS AND METHOD}

Standards and reagents: Rebaudioside A was from Sigma Aldrich; Rebaudioside B, C, D, stevioside, steviolbioside and dulcoside A were from TRC - Canada, other chemicals including acetonitrile, methanol, ammonium acetate, dichloromethan were from Merck.

System: LC-MS/MS (XEVO-TQD, Waters); C18 column (100 mm x $2.1 \mathrm{~mm}$ x $3.5 \mu \mathrm{m}$ ). Mobile phase: $5 \mathrm{mM}$ ammonium acetate in water and $0.1 \% \mathrm{CH}_{2} \mathrm{Cl}_{2}$ in $\mathrm{ACN}$ with ratio of $65: 35$, etc.

Samples: dried stevia, stevia leaves tea, stevia leaves materials, and soft drinks. Samples were collected randomly from markets in Hanoi.

Procedure: The amount of $0.1-1 \mathrm{~g}$ homogenized sample was weighed into a $50 \mathrm{ml}$ centrifugal tube. The amount of $30 \mathrm{ml}$ of methanol was added, then the tube was shaken with a vortex within one minute. The solution was ultrasonic extracted at $400^{\circ} \mathrm{C}$ within 60 minutes. After being centrifuged at $5000 \mathrm{rpm}$ within 5 minutes, the extract was transferred to a $50 \mathrm{~mL}$ volumetric flask. The residue was re-extracted with $15 \mathrm{~mL}$ of methanol. The extracts were combined into the $50 \mathrm{~mL}$ volumetric flask and made up to the mark with methanol, filtered through the filter paper. The filtrate was diluted with distilled water and loaded on SPE Oasis HLB column (500 mg, $3 \mathrm{ml}$ ). The column was conditioned with $3 \mathrm{~mL}$ methanol and $3 \mathrm{~mL} \mathrm{H}_{2} \mathrm{O}$. The sample was loaded at a rate of $2 \mathrm{ml} / \mathrm{min}$, washed with $3 \mathrm{ml} \mathrm{H}{ }_{2} \mathrm{O}$ and $3 \mathrm{ml} \mathrm{MeOH}$ : $\mathrm{H}_{2} \mathrm{O}$ (4: 6). The amount of $3 \mathrm{~mL} \mathrm{MeOH}: \mathrm{H}_{2} \mathrm{O}$ (7: 3) was eventually loaded on the column to elute. The elution was injected into the LC-MS/MS.

\section{RESULTS AND DISCUSSION}

\subsection{Chromatographic conditions}

\subsubsection{Mass spectrometry parameters}

The parameters of mass spectrometry for simultaneous determination of seven steviol glycosides were optimized automatically. The results were shown in Table 1.

Table 1. Parameters of steviol glycosides analysis on LC-MS / MS

\begin{tabular}{|c|c|c|c|c|c|c|c|}
\hline No. & Compouds & $\begin{array}{c}\text { Molecular } \\
\text { mass }\end{array}$ & $\begin{array}{c}\text { Retention } \\
\text { time } \\
(\boldsymbol{m i n})\end{array}$ & $\begin{array}{c}\text { Parent } \\
\text { ions } \\
(\boldsymbol{m} / \mathbf{z})\end{array}$ & $\begin{array}{c}\text { Product } \\
\text { ions } \\
(\boldsymbol{m} / \mathbf{z})\end{array}$ & $\begin{array}{c}\text { Cone } \\
\text { Volage } \\
(\text { V) }\end{array}$ & $\begin{array}{c}\text { Collision } \\
\text { Energy } \\
(\boldsymbol{E})\end{array}$ \\
\hline 1 & Steviolbioside (Stev B) & 642.73 & 5.09 & 641 & 480 & 70 & 40 \\
\hline 2 & Rebaudioside B (Reb B) & 804.87 & 5.00 & 803 & 317 & 70 & 40 \\
\hline 3 & Dulcoside A (Dul A) & 788.88 & 4.81 & 823 & 625 & 70 & 40 \\
\hline 4 & Steviolside (Stev) & 804.87 & 4.27 & 839 & 641 & 70 & 40 \\
\hline 5 & Rebaudioside C (Reb C) & 951.2 & 4.71 & 985 & 787 & 70 & 40 \\
\hline 6 & Rebaudioside A (Reb A) & 967.01 & 4.18 & 1,001 & 803 & 70 & 50 \\
\hline 7 & Rebaudioside D (Reb D) & $1,129.15$ & 2.87 & 1,163 & 803 & 70 & 40 \\
\hline
\end{tabular}

Steviol glycosides were ionized in both ESI (-) and ESI (+) modes. However, ESI (-) mode gave better ionization efficiency [5]. Stev B and Reb B were ionized according to the mechanism $[\mathrm{M}-\mathrm{H}]$ - while the remaining compounds were ionized based on the mechanism $[\mathrm{M}+\mathrm{Cl}]-$. Fragmentation in the collision cell occurs by removing of glycoside group to form ions [M-Glu]. Seven steviol glycosides were not completely separated. Nevertheless, they were well identified and quantified by mass spectrometry.

\subsubsection{Influence of dichloromethane, ammonium acetate on mobile phase}

The ion concentration in the mobile phase directly affects to the ionization and signals of the 
analyses. Based on the ion fragmentation mechanism and references [4], it was found that the signal of steviol glycoside was affected by dichloromethane and ammonium acetate concentrations in the mobile phase as presented in Table 2 and Table 3.

Table 2. Influence of dichloromethane on mobile phase

\begin{tabular}{|c|c|c|c|c|}
\hline [CH2C12] (\%) & 0.02 & 0.05 & 0.1 & 0.5 \\
\hline Stev & 1,476 & 1,537 & 1,603 & 1,585 \\
\hline Reb A & 6,056 & 6,205 & 6,443 & 6,412 \\
\hline Reb B & - & - & - & - \\
\hline Reb C & 1,013 & 1,234 & 1,455 & 1,323 \\
\hline Reb D & 435 & 507 & 520 & 505 \\
\hline Dul A & 2,302 & 2,324 & 2,445 & 2,343 \\
\hline Stev B & - & - & - & - \\
\hline
\end{tabular}

Table 3. Influence of ammonium acetate on mobile phase

\begin{tabular}{|c|c|c|c|c|c|}
\hline Compounds & 1 & 2 & 5 & 10 & 20 \\
\hline Stev & 1,324 & 1485 & 1,603 & 1,665 & 1,571 \\
\hline Reb A & 6,257 & 6,375 & 6,443 & 6,440 & 6,438 \\
\hline Reb B & 8,087 & 15,435 & 18,919 & 18,789 & 17,793 \\
\hline Reb C & 1,068 & 1,324 & 1,455 & 1,343 & 1,371 \\
\hline Reb D & 452 & 513 & 520 & 518 & 522 \\
\hline Dul A & 2,211 & 2,234 & 2,445 & 2,434 & 2,462 \\
\hline Stev B & 4,418 & 4,723 & 4,835 & 4,832 & 4,825 \\
\hline
\end{tabular}

The signal of steviol glycosides was increased when the concentration of $\mathrm{CH}_{2} \mathrm{Cl}_{2}$ and $\mathrm{NH}_{4} \mathrm{OOCCH}_{3}$ increased. However, when the concentration of $\mathrm{CH}_{2} \mathrm{Cl}_{2}$ was higher than $0.1 \%$ and the concentration of $\mathrm{NH}_{4} \mathrm{OOCCH}_{3}$ was higher than $5 \mathrm{mM}$, the signals was decreased, probably ionic competition. The signal was the highest when the concentrations of $\mathrm{CH}_{2} \mathrm{Cl}_{2}$ and $\mathrm{NH}_{4} \mathrm{OOCCH}_{3}$ were at $0.1 \%$ and $5 \mathrm{mM}$, respectively. These values were selected for subsequent steps.

\subsection{Sample preparation}

Steviol glycosides can be dissolved in polar solvents such as water or methanol because aglycol structures associated with sugar moieties. Solvents including water, mixture of water and methanol $(5: 5, \mathrm{v} / \mathrm{v})$, mixture of water and methanol $(2: 8, \mathrm{v} / \mathrm{v})$ and methanol were investigated for extraction. The results showed the highest content of steviol glycosides obtained with methanol. The recoveries of Stev, Reb B and Stev B were low when the extract solvent contained high water ratio and it was reversed when the amount of methanol in the extract solvent was high. Reb A, Reb C, Reb D and Dul A compounds were not affected by these solvents.

The extract time of 15, 30, 60, 90 minutes were tested. Results showed that the content of steviol glycosides increased when the extraction time rose. As the extract time was longer than 60 minutes, there was no significant difference in the steviol glycoside content. Therefore, the 60 minute duration 
was selected for subsequent steps.

Solid phase extraction technique was chosen to clean up sample extract before injecting into LC-MS/MS. C18 SPE column (500 mg, $3 \mathrm{~mL}$ ) and Oasis HLB column (500 mg, $3 \mathrm{ml}$ ) were investigated. The results showed that the Oasis HLB column exhibit better performance (the recovery of $92.6-100 \%$ ) compared to C18 column (the recovery of $50.0-95.1 \%$ ). Thus, Oasis HLB column was selected to clean up the sample in this study.

\subsection{Method validation}

The specificity of the method was assessed through analysis of blank, standard and spiked samples. No signal was on the blank sample chromatogram. The retention time of steviol glycosides on the standard sample chromatogram was similar to that on the spike sample chromatogram, showing that the method had good specificity. Fig. 1 showed chromatogram of a mixture as the concentration level of $5 \mathrm{mg} / \mathrm{mL}$ of seven steviol glycosides in the optimal conditions.

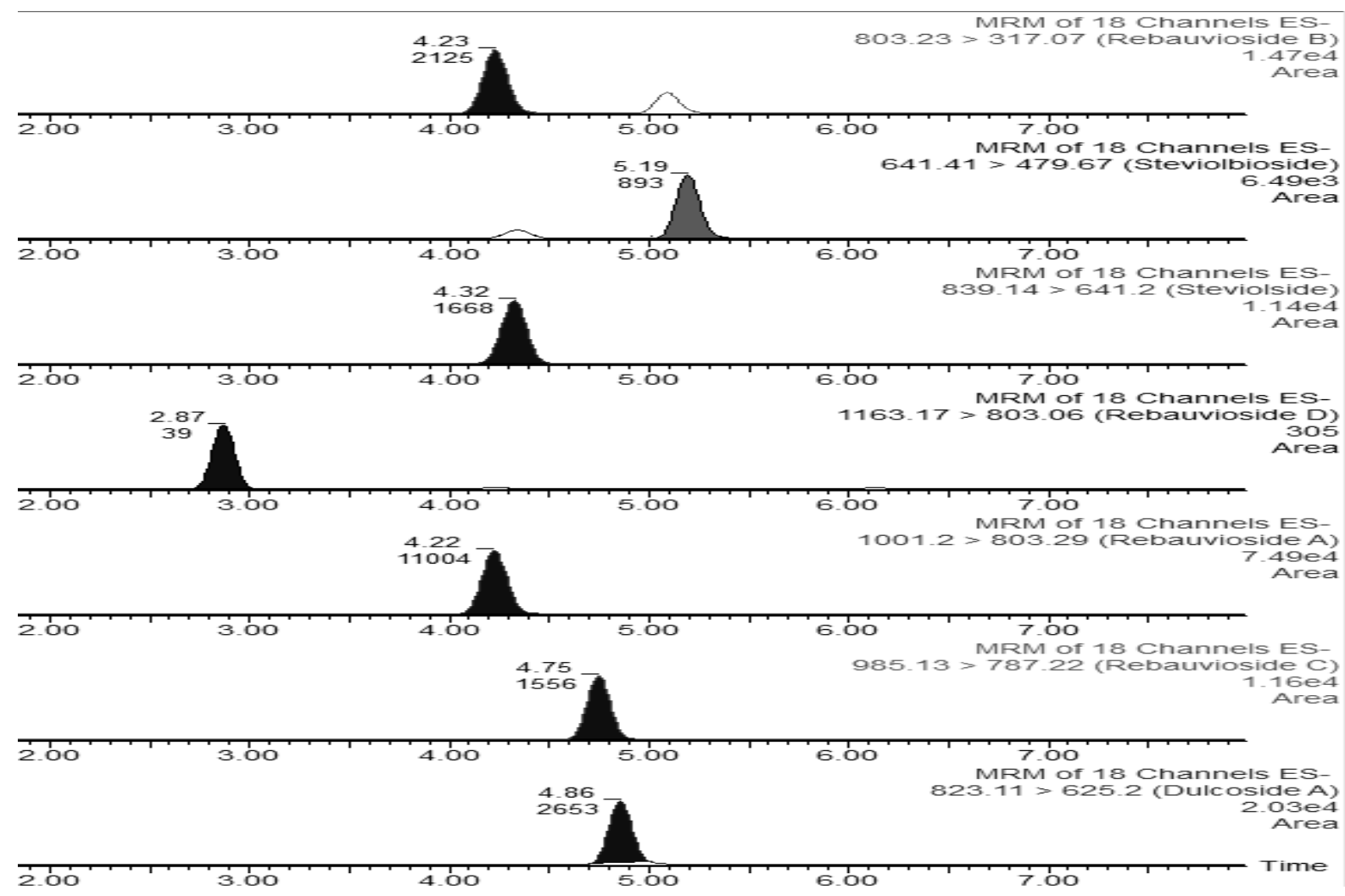

Figure 1. Chromatogram of a mixture of as the concentration level of $5 \mathrm{mg} / \mathrm{mL}$ seven steviol glycosides

Calibration curve of seven steviol glycosides was established using optimal analytical conditions with the concentration range of $0.1-20 \mu \mathrm{g} / \mathrm{mL}$. The results of the calibration equation, the linearity coefficient, limit of detection (LOD) and the limit of quantitation (LOQ), the repeatability (RSD) and the recovery $(\mathrm{R})$ were described in Table 4.

Table 4. Results of method validation parameters

\begin{tabular}{|l|c|c|c|c|c|c|}
\hline \multicolumn{1}{|c|}{ Compound } & $\begin{array}{c}\text { Standard curve } \\
\text { equations }\end{array}$ & $\boldsymbol{R}^{\mathbf{2}}$ & $\begin{array}{c}\mathbf{L O D} \\
(\boldsymbol{\mu g} / \mathbf{m L} \boldsymbol{L})\end{array}$ & $\begin{array}{c}\mathbf{L O Q} \\
(\boldsymbol{\mu g} / \boldsymbol{m} \boldsymbol{L})\end{array}$ & $\boldsymbol{R S D}(\%)$ & $\boldsymbol{R}(\%)$ \\
\hline Stevioside & $\mathrm{y}=1,515.8 \mathrm{x}+42.778$ & 0.9996 & 4 & 13.2 & $2.59-3.45$ & $93-101$ \\
\hline Rebaudioside A & $\mathrm{y}=6,281.5 \mathrm{x}+111.17$ & 0.9997 & 0.065 & 0.22 & $2.29-5.01$ & $95-103$ \\
\hline Rebaudioside C & $\mathrm{y}=1,507.1 \mathrm{x}-145.99$ & 0.9998 & 0.15 & 0.51 & $2.04-3.68$ & $96-99$ \\
\hline
\end{tabular}


SCIENTIFIC RESEARCH

\begin{tabular}{|l|l|c|c|c|c|c|}
\hline Dulcoside A & $\mathrm{y}=2,966 \mathrm{x}-627.06$ & 0.9994 & 0.1 & 0.34 & $2.42-3.69$ & $95-104$ \\
\hline Rebaudioside B & $\mathrm{y}=1,8950 \mathrm{x}-613.25$ & 0.9996 & 0.01 & 0.034 & $3.32-3.70$ & $96-105$ \\
\hline Rebaudioside D & $\mathrm{Y}=520.4 \mathrm{x}+22.891$ & 1.0000 & 0.15 & 0.51 & $1.74-4.45$ & $92-103$ \\
\hline Steviolbioside & $\mathrm{Y}=4,813 \mathrm{x}-66.867$ & 0.9999 & 0.06 & 0.20 & $2.94-3.51$ & $90-103$ \\
\hline
\end{tabular}

The linearity coefficient $\mathrm{R}^{2}>0.99$ for all analyses, repeatability and recovery are satisfactory according to AOAC.

\subsection{Evaluation of steviol glycosides content in some food samples}

Determination of steviol glycoside content in 19 samples including seven stevia leaf samples, three stevia material samples, three stevia tea samples and six beverage samples was carried out. The results were shown in Table 5.

Table 5. Steviol glycoside content in some food samples

\begin{tabular}{|c|c|c|c|c|c|c|c|c|}
\hline No. & Sample & $\begin{array}{c}\text { Stev } \\
(\mathrm{mg} / \mathrm{g})\end{array}$ & $\begin{array}{l}\operatorname{Reb} A \\
(m g / g)\end{array}$ & $\begin{array}{l}\text { Reb C } \\
(m g / g)\end{array}$ & $\begin{array}{l}\text { Dul } A \\
(m g / g)\end{array}$ & $\begin{array}{l}\operatorname{Reb} B \\
(m g / g)\end{array}$ & $\begin{array}{l}\text { Reb D } \\
(m g / g)\end{array}$ & $\begin{array}{l}\text { Stev B } \\
(\mathrm{mg} / \mathrm{g})\end{array}$ \\
\hline 1 & Stevia leaves 1 & 30.5 & 10.5 & 3.3 & 0.04 & - & - & - \\
\hline 2 & Stevia leaves 2 & 54.5 & 8.1 & 2.1 & 0.15 & - & 0.05 & - \\
\hline 3 & Stevia leaves 3 & 40.5 & 9.2 & 1.2 & 0.05 & - & - & - \\
\hline 4 & Stevia leaves 4 & 19.5 & 5.4 & 0.21 & - & - & 0.04 & - \\
\hline 5 & Stevia powder 1 & 60.9 & 4.5 & 3.1 & 1.5 & - & - & - \\
\hline 6 & Stevia powder 2 & 57.5 & 3.4 & 2.1 & 0.7 & 0.01 & - & - \\
\hline 7 & Stevia branches & 1.32 & 0.16 & 0.29 & - & - & - & - \\
\hline 8 & Diet sugar 1 & 1.17 & 2.3 & 7.6 & - & - & - & - \\
\hline 9 & Diet sugar 2 & 3.12 & 2.52 & 1.12 & - & - & - & - \\
\hline 10 & Diet sugar 3 & 8.15 & 2.15 & 2.1 & - & - & - & - \\
\hline 11 & Weight loss tea 1 & 0.52 & 0.12 & - & - & - & - & - \\
\hline 12 & Weight loss tea 2 & 1.05 & 0.25 & 0.11 & - & - & - & - \\
\hline 13 & Weight loss tea 3 & 2.02 & 0.22 & - & - & - & - & - \\
\hline 14 & Beverage 1 & 0.002 & 0.013 & 0.015 & - & - & - & - \\
\hline 15 & Beverage 2 & 0.006 & 0.001 & - & - & - & - & - \\
\hline 16 & Beverage 3 & 0.0021 & 0.001 & 0.001 & - & - & - & - \\
\hline 17 & Beverage 4 & - & - & - & - & - & - & - \\
\hline 18 & Beverage 5 & 0.005 & 0.001 & - & - & - & - & - \\
\hline 19 & Beverage 6 & 0.004 & 0.002 & 0.002 & - & - & - & - \\
\hline
\end{tabular}

The content of steviol glycoside varied in different samples, possibly due to crop conditions and harvest season. The total content of steviol glycoside was of $25-65 \mathrm{mg} / \mathrm{g}, 63-68 \mathrm{mg} / \mathrm{g}, 6-12$ $\mathrm{mg} / \mathrm{g}, 0.6-2.2 \mathrm{mg} / \mathrm{g}$, and $0.007-0.03 \mathrm{mg} / \mathrm{g}$ in stevia leaf, leaves powder, diet sugar, weight loss tea, and beverage samples, respectively. Stevioside and rebaudioside A were the highest contents, which were consistent with previous studies on the composition of stevia sugars. The ratio of substance content in beverage samples corresponded to the proportion in the material samples.

\section{CONCLUSION}

The study was successful in simultaneous determining seven steviol glucosides by LC-MS/MS and applying to steviol glycoside determination in some food and material samples. The method was quick and simple with high level of sensitivity and accuracy. 


\section{REFERENCES}

1. Tôn Nữ Liên Hương, Võ Hoàng Duy, Dương Mộng Hòa, Đỗ Duy Phúc và Nguyễn Duy Thanh, (2015) "Chiết xuất Stevioside từ cây cỏ ngọt”, Tạp chí khoa học trường đại học Cần Thơ, Phần A: Khoa học tự nhiên, công nghệ và môi trường: 36 (2015):73-76

2. Nguyễn Kim Cẩn, Lê Nguyệt Nga (2001), “Định lượng stevioside trong lá cỏ ngọt”, Công trình nghiên cứu khoa học 1987-2000, Viện dược liệu, Nhà Xuất bản Khoa học và Kỹ thuật: 125-128.

3. Annie Shirwaikar, Vinit Parmar, Jay Bhagat and Saleemulla Khan ( 2011), "Identification and estimation of stevioside in the commercial samples of stevia leaf and powder by HPTLC and HPLC,Int. J. of Pharm. \& Life Sci. (IJPLS), 2, 9, 1050-1058.

4. Claudio Gardana, Martina Scaglianti, Paolo Simonetti (2010) "Evaluation of steviol and its gly cosides in Stevia rebaudiana leaves and commercial sweetener by ultra-high-performance liquid chromatography-mass spectrometry" Journal of Chromatography A, 1217 (2010) 1463-1470.

5. Molina-Calle, M., Sánchez de Medina, V., Delgado de la Torre, M. P., Priego-Capote, F., \& Luque de Castro, M. D. (2016). "Development and application of a quantitative method based on L-QqQ MS/MS for determination of steviol glycosides in Stevia leaves". Talanta, 154(C), 263-269.

6. Paweł Kubica, Jacek Namieśnik, Andrzej Wasik (2015) "Determination of eight artificial sweet eners and common Stevia rebaudiana glycosides in non-alcoholic and alcoholic bev erages by reversed-phase liquid chromatography coupled with tandem mass spectrometry" Anal Bioanal Chem, 2015 Feb, 407(5):1505-12

7. R. Amery, E. Jooken, J. Geuns4 and B. Meesschaert. "Determination of steviol glycosides in Various dairy matrices and soy drink". Centre for Surface Chemistry and Catalysis and Leuven Food Science and Nutrition Research Centre; 2010; Vol. 4; pp.69-82

\section{Tóm tắt}

\section{NGHIÊN CÚU PHƯƠNG PHÁP XÁC ĐİNH MỘT SỐ STEVIOL GLYCOSIDE TRONG THỬC PHẨM TƯ CỎ NGỌT BẰNG PHƯƠNG PHÁP SĂC KÝ LỎNG KHỐI PHỔ (LC-MS/MS)}

\section{Luu Thị Huyền Trang, Vũ Thị Kim Oanh, Vũ Thị Trang, Nguyễn Thị Biển \\ Viện Kiểm nghiệm an toàn vệ sinh thực phẩm Quốc gia}

Nghiên cứu này phát triển phương pháp xác định đồng thời mốt số steviol glycoside trong nền mẫu thực phẩm bằng LC-MS/MS. Các chất phân tích được chiết siêu âm ra khỏi nền mẫu bằng methanol ở $40^{\circ} \mathrm{C}$ trong 60 phút, tách bằng sắc ký lỏng sử dụng cột $\mathrm{C} 18(100 \mathrm{~mm} \times 2 \mathrm{~mm}$ $\mathrm{x} 3,5 \mu \mathrm{m}$ ), định lượng bằng detector khối phổ với chế độ ESI (-). Thẩm định phương pháp cho kết quả đường chuẩn tuyến tính trong khoảng $0,1-20 \mu \mathrm{g} / \mathrm{mL}$; RSD 1,74 - 5,01\%; độ thu hồi 90 - 105\% đạt yêu cầu AOAC. Úng dụng phương pháp phân tích 19 mẫu thực phẩm thu thập trên thị trường (bao gồm cỏ ngọt khô, đường nguyên liệu cỏ ngọt, trà cỏ ngọt, nước giải khát) cho thấy thành phần các steviol glycoside khác nhau trong các đối tượng mẫu khác nhau nhưng hàm lượng chiếm tỷ lệ lớn là stevioside và steviodioside $\mathrm{A}$.

Tù̀ khóa: LC-MS, steviol glycoside, thực phẩm 